Звєкова Вікторія Корніївна кандидат педагогічних наук, доцент, завідуюча кафедрою загальної педагогіки і спеціальної освіти, Ізмаїльський державний гуманітарний університет, вул. Рєпіна, 12, м. Ізмаїл, 68600, тел.: (067) 267-56-45, e-mail:vikazvekova19@gmail.com, https://orcid.org/0000-0002-6044-8814

\title{
РОЗВИТОК СЕНСОРНОГО ВИХОВАННЯ ОСОБИСТОСТІ В ДОШКІЛЬНОМУ ДИТИНСТВІ
}

Анотація. Процес пізнання людиною навколишнього світу починається 3 відчуттів i сприйняття предметів i явищ. Всі форми пізнання - уява, запам'ятовування, мислення - будуються на тій основі, яку створюють образи сприйняття. У дошкільному дитинстві чуттєве пізнання відіграє особливу роль, оскільки саме цей вік особливо сприятливий для розвитку і вдосконалення органів почуттів i накопичення уявлень про навколишню дійсність. Відображення цієї дійсності забезпечують сенсорні процеси, і саме від рівня їх розвитку буде залежати характер уявлень, їх точність, повнота і ясність. Тому розвиток сприйняття забезпечує як розвиток сенсорних процесів в цілому, так i подальший розвиток пізнавальних процесів [7].

На етапі переходу від чуттєвого до раціонального пізнання, від сприйняття до мислення, в період, коли закладаються основи подальшої інтелектуальної діяльності, сенсорне виховання є важливим і невід'ємним процесом. Чуттєве i раціональне пізнання виступають як різні сторони єдиного процесу пізнання дитиною навколишнього світу, як різні форми пізнавальної діяльності, які знаходяться між собою в органічному взаємозв'язку. Тому так важливо розвивати сенсорні процеси, що також грає істотну роль в удосконаленні практичної діяльності дитини.

Ознайомлення 3 сенсорною культурою людини реалізується в певній системі, завдяки якій дитина поступово засвоює накопичений людством потенціал у формі сенсорних еталонів. Сенсорне виховання в дошкільному дитинстві $\epsilon$ основним і практично єдиним видом виховання. Починаючи відкривати навколишній світ, маленька дитина вбирає в себе потоки сенсорної інформації, що складається з нових яскравих вражень. Це необхідно не тільки для розвитку діяльності органів почуттів, але і для загального нормального розвитку як фізичного, так і психічного. Обмеженість припливу вражень змушує малюка відчувати «сенсорний голод», що призводить до серйозних затримок загального розвитку. У цей період необхідно забезпечити дитині багаті і різноманітні зовнішні враження, розвивати увагу до властивостей предметів.

Ключові слова: сенсорне виховання, дошкільник, культура, інформація, розвиток дитини 
Zvekova Victoria Korniivna Candidate of Pedagogical Sciences, Associate Professor, Head of the Department of General Pedagogy and Special Education, Izmail State University for the Humanities, 68600, Izmail, 12 Repina St., tel.: (067) 267-5645, e-mail:vikazvekova19@gmail.com, https://orcid.org/0000-0002-6044-8814

\section{DEVELOPMENT OF SENSORY EDUCATION OF PERSONALITY IN PRESCHOOL CHILDHOOD}

Abstract.The process of human cognition of the world around us begins with the sensations and perceptions of objects and phenomena. All forms of cognition imagination, memorization, thinking - are built on the basis created by images of perception. In preschool childhood, sensory cognition plays a special role, because this age is especially favorable for the development and improvement of the senses and the accumulation of ideas about the surrounding reality. The reflection of this reality is provided by sensory processes, and the nature of representations, their accuracy, completeness and clarity will depend on the level of their development. Therefore, the development of perception provides both the development of sensory processes in general and the further development of cognitive processes [7].

At the stage of transition from sensory to rational cognition, from perception to thinking, in the period when the foundations of further intellectual activity are laid, sensory education is an important and integral process. Sensory and rational cognition act as different aspects of a single process of cognition of the world around the child, as different forms of cognitive activity, which are in an organic relationship with each other. That is why it is so important to develop sensory processes, which also plays a significant role in improving the practical activities of the child.

Acquaintance with the sensory culture of man is realized in a certain system, through which the child gradually learns the potential accumulated by mankind in the form of sensory standards. Sensory education in preschool is the main and almost the only type of education. Beginning to discover the world around him, a small child absorbs streams of sensory information, consisting of new vivid impressions. This is necessary not only for the development of the senses, but also for the overall normal development of both physical and mental. Limited influx of impressions makes the baby feel "sensory hunger", which leads to serious delays in overall development. During this period it is necessary to provide the child with rich and various external impressions, to develop attention to properties of subjects.

Keywords: sensory education, preschooler, culture, information, child development

Постановка проблеми. На етапі переходу від чуттєвого до раціонального пізнання, від сприйняття до мислення, в період, коли закладаються основи подальшої інтелектуальної діяльності, сенсорне виховання $\epsilon$ важливим i невід'ємним процесом. Чуттєве і раціональне пізнання виступають як різні сторони єдиного процесу пізнання дитиною навколишнього світу, як різні форми пізнавальної діяльності, які знаходяться між собою в органічному взаємозв'язку. 
Тому так важливо розвивати сенсорні процеси, що також грає істотну роль в удосконаленні практичної діяльності дитини. Рівень чутливості до сенсорних подразників у різних людей суттєво різниться. На це впливають такі фактори, як спадковість, стан органів почуттів, розвиток органів почуттів і сприйняття. Здатність людини сприймати різні зовнішні подразники 15 за допомогою органів почуттів, дана від природи, може розвиватися в процесі спонтанного вивчення світу. Також для її розвитку може застосовуватися спеціальне навчання. I в тому i в іншому випадку необхідно надання для сприйняття різноманітних сенсорних подразників. Згідно з останніми дослідженнями, відчуття і сприйняття є особливі дії аналізаторів, спрямовані на обстеження предмета і його відмінних рис. Обстеження - це спеціально організоване сприйняття предметів, яке дозволяє використовувати його результати в різної змістовної діяльності. Обстеження $\epsilon$ основним методом сенсорного виховання дітей раннього віку [9].

За допомогою обстеження дитина здатна опановувати узагальненими способами чуттєвого пізнання, якими він зможе скористатися в самостійної діяльності. Педагог же в свою чергу повинен створити спеціальні умови, що дозволяють дітям застосувати отримані ними знання і навчитися аналізувати навколишнє середовище [9].

Важливо пам'ятати, чим раніше починається сенсорне виховання дитини, тим швидше він буде розвиватися після, тим краще буде навчатися. Важливість процесу сенсорного виховання для дитини та іiі подальшого розвитку і життя ставить перед дошкільної педагогікою i вихованням завдання розробити i використовувати найбільш продуктивні засоби і методи сенсорного виховання дітей раннього віку в дошкільній освітній організації.

Таким чином, сенсорне виховання - це цілеспрямований педагогічний вплив, спрямований на формування чуттєвого пізнання, вдосконалення відчуттів i сприйняття, накопичення дитиною сенсорного досвіду і формування уявлень про навколишній світ.

Результатом цього процесу є сенсорний розвиток дитини, яке представляє собою розвиток його сприйняття і формування уявлень про форми, кольори, величини, положенні в просторі, а також про запах, смак і інших зовнішніх властивостях предметів.

Сенсорні процеси - це процеси, пов'язані з формуванням і зміною відчуттів дитини, його сприйняття і уявлень, вони нерозривно пов'язані 3 діяльністю органів почуттів, саме на їх розвиток і направлено сенсорне виховання.

Аналіз останніх досліджень і публікацій. Ознайомлення 3 сенсорною культурою людини реалізується в певній системі, завдяки якій дитина поступово засвоює накопичений людством потенціал у формі сенсорних еталонів. В цілому вітчизняна система сенсорного виховання [12] спирається на теорію сприйняття, розроблену видатними педагогами та психологами (Л. Виготським, Б. Ананьєва, С. Рубінштейном, А. Леонтьєвим, А. Запорожцем, Л. Венгером). Визначення актуальних проблем сенсорного виховання і навчання дітей раннього віку були використані в роботах I. Беха; особливості розвитку сенсорних здібностей за допомогою дидактичних ігор займалися Г. Тарасенко, Г. Березюк; розвитком 
сенсорної культури було розроблено в працях В. Кошель, Л.Артемової, А.М.Богуш та інші.

Мета статті - теоретичне дослідження та обгрунтування особливостей розвитку сенсорного виховання у дітей з дошкільного дитинства.

Виклад основного матеріалу. Сенсорне виховання тісно пов'язане 3 таким поняттям, як «сенсорний розвиток», яке, за визначенням I. Бех, являє собою роботу 3 розвитку сприйняття дитини 3 метою сформувати уявлення про предмети і їх зовнішні властивості, таких як величина, знаходження і положення в просторі, запах і смак, колір, форма [2]. Завдяки сенсорному вихованню дитина починає більш повно сприймати різні предмети, різноманітність їх властивостей $і$ відносин. Дослідження, що проводяться в галузі педагогіки і психології, показують, що без подібного впливу сприйняття дитини надовго залишається поверхневим, уривчастих, не виникає фундамент і придбання навичок. Головною метою сенсорного виховання є оволодіння дитиною сенсорної культурою.

Завдяки роботам В. Кошель [6], поняття «сенсорна культура» міцно увійшло в дошкільну педагогіку. Сенсорна культура - поняття, яке позначає рівень відчуттів і сприйняття дитини, як основу його успішної пізнавальної діяльності. Особливе значення вона отримує в умінні розрізняти висоту і тембр звуків, їх тривалість і силу; кольори і відтінки; форми, поєднання форм i кольорів. Освоєння сенсорної культури допомагає кращому розумінню творів образотворчого і музичного мистецтва, дозволяє отримувати задоволення від розглядання картин, скульптур, прослуховування музики [6].

Як вважає I. Бех [2], під сенсорною культурою слід розуміти загальноприйняті уявлення про колір, форму та інші властивості речей, також вона є результатом засвоєння дитиною сенсорної культури, створеної людством.

Л. Артемова [1], визначає сенсорну культуру як сукупність сприймаються i відчутних явищ дійсності на емоційному рівні. Він пише про те, що пізнання людиною навколишнього світу починається 3 «живого споглядання» сприйняття, відчуттів, уявлень. Все це і створює сукупність сенсорної культури. Для того, щоб вирішити пізнавальні завдання, які ставить сенсорна культура, існують спеціальні засоби, звані сенсорними еталонами.

Поняття «сенсорні еталони» розроблено К. Крутій [5] в рамках теорії формування перцептивних дій. Сенсорні еталони - це система чуттєвих якостей предметів, які виділилися в процесі суспільно-історичного розвитку та запропоновано дитині, щоб він міг засвоїти і використати їх в якості зразків при дослідженні об'єктів і аналізі їх властивостей. Освоєння сенсорних еталонів служить основою соціалізації дитини з перших років життя.

В ході свого розвитку людство виділило еталонну систему величин, яка дозволила їх нескінченну різноманітність звести до небагатьох основних різновидів. Пізнаючи цю систему, дитина отримує набір зразків, що дозволяє зіставити i розпізнати будь-який знову сприйняте якість i дати йому належне визначення

Сенсорні еталони кольору представляють сім кольорів спектра та їх відтінки по яскравості і насиченості. Форму як сенсорних еталонів характеризують п’ять 
фігур. Еталонні величини - метрична система заходів, міри ваги, а також звуковисотний ряд, система фонем рідної мови.

Оволодіння дитиною системою сенсорних еталонів i $\ddot{1} x$ словесними позначеннями має конкретний результат, виражений в отриманні сенсорного досвіду, який представляє накопичений запас відчуттів і сприйнять, одержуваних в ході оволодіння сенсорної культурою в процесі сенсорного виховання.

Таким чином, засвоєння сенсорних еталонів - це використання їх при оцінці властивостей речовин в якості «одиниць виміру». У своїй науковій роботі І. Бех [2] виділив і досліджував два шляхи засвоєння систем сенсорних еталонів перцептивний i інтелектуальний. Перцептивний став основою для розробки способів і методів сенсорного виховання дітей раннього та дошкільного віку, тому що саме перцептивні дії допомагають вивчити основні властивості і якості сприймаються предметів, виділяючи 3 них головні і другорядні [2]. Грунтуючись на цьому процесі дитина сприймає інформативні точки в кожному 3 предметів навколишнього світу, що дозволяє при повторному сприйнятті швидко дізнаватися цей предмет, відносячи його до певного класу - лялька, машинка, ложка. Зовнішні і розгорнуті дії сприйняття, коли дитина не тільки дивиться на предмет, але i зворушує його руками, маніпулює 3 ним, потім переходять у внутрішній план, де автоматизуються.

Так розвиток перцептивних дій бере участь у формуванні узагальнень. Таким чином, основний зміст сенсорного виховання в дошкільній освітній організації полягає в знайомстві з головними властивостями предметів - формою, величиною і кольором, які мають визначальне значення в процесі формування уявлень про предмети i явища дійсності. Чітке сприйняття, $\epsilon$ запорукою успішного засвоєння навчального матеріалу і формування здібностей до багатьох видів творчої діяльності [2].

Виділяють три напрямки розвитку сприйняття: через перцептивні дії, через сенсорні еталони і через дії співвіднесення. Виділення найбільш характерних для даного предмета, явища або ситуації якостей (інформативних точок), складання на їх основі стійких образів (сенсорних еталонів) і співвіднесення цих образіветалонів 3 предметами навколишнього світу визначають процес формування сприйняття.

Відомий вчений Н. Грама [3] вважає, що всі діти народжуються без будьяких ознак інтелекту, але коріння думки у дитини лежать в відчутті. Перш ніж почати мислити, дитина пізнає навколишній світ за допомогою своїх органів почуттів (зір, слух, дотик). Як уже зазначалося, це пізнання починається 3 відчуттів і сприйняття, тобто чуттєвого відображення в мозку дитини предметів і явищ навколишнього дійсності. Цілісне сприйняття конкретного предмета складається з окремих відчуттів, які спираються на попередній досвід [3].

Сенсорне виховання в дошкільному дитинстві $\epsilon$ основним i практично єдиним видом виховання. Починаючи відкривати навколишній світ, маленька дитина вбирає в себе потоки сенсорної інформації, що складається 3 нових яскравих вражень. Це необхідно не тільки для розвитку діяльності органів почуттів, але i для загального нормального розвитку як фізичного, так i 
психічного. Обмеженість припливу вражень змушує малюка відчувати «сенсорний голод», що призводить до серйозних затримок загального розвитку. У цей період необхідно забезпечити дитині багаті і різноманітні зовнішні враження, розвивати увагу до властивостей предметів.

Яскраво виражену сенсорну основу мають і здібності, тому так важливо не упустити період раннього дитинства, є сенситивним для сенсорного виховання. Як уже зазначалося, пізнання навколишнього світу відбувається за допомогою таких процесів, як відчуття і сприйняття. Вплив предмета або явища (подразника) на наші органи чуття $\epsilon$ необхідною умовою для виникнення відчуттів. Ще стародавні греки розрізняли п'ять органів почуттів і відповідні їм відчуття, серед яких виділяються зорові, слухові, дотикові, нюхові, смакові.

Рівень чутливості до сенсорних подразників у різних людей суттєво різниться. На це впливають такі фактори, як спадковість, стан органів почуттів, розвиток органів почуттів і сприйняття. Здатність людини сприймати різні зовнішні подразники за допомогою органів почуттів, дана від природи, може розвиватися в процесі спонтанного вивчення світу. Також для їі розвитку може застосовуватися спеціальне навчання. I в тому і в іншому випадку необхідно надання для сприйняття різноманітних сенсорних подразників. Згідно 3 останніми дослідженнями, відчуття і сприйняття $\epsilon$ особливі дії аналізаторів, спрямовані на обстеження предмета і його відмінних рис. Обстеження - це спеціально організоване сприйняття предметів, яке дозволяє використовувати його результати в різної змістовної діяльності. Обстеження є основним методом сенсорного виховання дітей раннього віку [3].

За допомогою обстеження дитина здатна опановувати узагальненими способами чуттєвого пізнання, якими він зможе скористатися в самостійної діяльності. Педагог же в свою чергу повинен створити спеціальні умови, що дозволяють дітям застосувати отримані ними знання і навчитися аналізувати навколишнє середовище [3].

Важливо пам'ятати, чим раніше починається сенсорне виховання дитини, тим швидше він буде розвиватися після, тим краще буде навчатися. Важливість процесу сенсорного виховання для дитини та їі подальшого розвитку і життя ставить перед дошкільної педагогікою i вихованням завдання розробити i використовувати найбільш продуктивні засоби і методи сенсорного виховання дітей раннього віку в дошкільній освітній організації.

Сенсорні процеси - це процеси, пов'язані з формуванням і зміною відчуттів дитини, його сприйняття i уявлень, вони нерозривно пов’язані 3 діяльністю органів почуттів, саме на їх розвиток i направлено сенсорне виховання. Сенсорний розвиток відбувається в ході засвоєння суспільного сенсорного досвіду, під впливом практики та навчання. Ефективність сенсорного розвитку підвищується, якщо дитину навчають спеціальним способам обстеження i порівняння предметів із застосуванням сенсорних еталонів. У сучасній педагогіці i психології виділяють два методи сенсорного розвитку - обстеження i порівняння.

Обстеження як метод сенсорного розвитку проходить по двох напрямках: по 
контуру або за обсягом, вибір виду обстеження залежить від цілей і діяльності дитини. Так, коли ми вивчаємо з дошкільнятами властивості паперу, діти можуть пом’яти папір, обмацати іiі, розірвати, опустити в воду. Щоб сформувати образ персика, необхідно помацати фрукт, понюхати його, відчути смак. В ході такої роботи важливо навчити дітей виділяти суттєві ознаки предметів для певної мети і діяльності.

Ефективним методом сенсорного розвитку є порівняння, яке представляє собою дидактичний метод $\mathrm{i}$ розумову операцію одночасно. Порівняння встановлює подібність і відмінність певних предметів, явищ або їх частин. Порівняння буває декількох видів: зіставлення, обмацування, угруповання, послідовний огляд i опис. За допомогою порівняння поверхневе сприйняття предмета змінюється певним та детальним сприйняттям, допомагає формуванню правильних уявлень, створює основу для узагальнення та систематизації знань [4].

Висновки. Таким чином, сенсорне виховання - це цілеспрямований педагогічний вплив, спрямований на формування чуттєвого пізнання, вдосконалення відчуттів і сприйняття, накопичення дитиною сенсорного досвіду і формування уявлень про навколишній світ.

Результатом цього процесу є сенсорний розвиток дитини, яке представляє собою розвиток його сприйняття i формування уявлень про форми, кольори, величини, положенні в просторі, а також про запах, смак і інших зовнішніх властивостях предметів. Грамотно організоване середовище являє собою обладнану групову кімнату, обдуманий підбір іграшок, барвисті і продуктивні тренажери [7]. Також сучасне розвиваюче середовище повинна передбачати зону найближчого розвитку. Кожному педагогу необхідно вміти організовувати таку предметно-розвиваюче середовище в дошкільної освітньої організації, яка буде сприяти сенсорному вихованню 3 раннього віку, оскільки це $є$ одним 3 найважливіших показників розвитку гармонійної особистості дитини [7].

\section{Лimepamypa:}

1. Артемова Л. В. Пріоритети в підготовці педагогів дошкільного профілю. Дошк. виховання. 2002. № 2. С. 7-9.

2. Бех І.Д. Виховання особистості: У 2 кн. К., 2003

3. Богуш А. М. Підготовка студентів до здійснення наступності дошкільної і початкової ланок у системі безперервної освіти. Наука і освіта. 2009. № 4 . С. 61-63

4. Грама Г.П. Сенсорно-пізнавальний розвиток дітей другого року життя у найближчому предметному довкіллі. Збірник наукових доповідей. П Міжннар. Наук.-практ. Конфер. «Актуальні проблеми сучасної дошкільної та вищої освіти (30.052016 -31.05.2016) Warshava. Wydawca. 2016. C. 78-82.

5. Калуська Л. В. Комплексна програма розвитку, навчання та виховання дітей дошкільного віку. Тернопіль: Мандрівець, 2014. 144 с.

6. Кошель В.М. Сенсорне виховання дітей раннього віку. Чернігів: ФОП Баликіна О.В., 2019160 с.

7. Непомняща I. Розвиток словесної творчості у дітей раннього віку в умовах ДНЗ. ПНПУ ім. К.Д. Ушинського, Педагогічний альманах: зб.студ.наук. статей м. Одеса, 2015. С. 240-244.

\section{References:}

1. Artemova L. V. (2002) Priorytety u pidhotovtsi vchyteliv doshkil'nykh zakladiv. [Priorities in the training of preschool teachers. Council. Education] Rada. osvity. № 2. S. 7-9. [in Ukrainian]. 
2. Bekh I.D.(2003) Vykhovannya osobystosti: U 2 -kh kn. [Education of personality: In 2 books] K.,

3. Bohush A. M. (2009) Pidhotovka uchniv do realizatsiyi bezperervnosti doshkil'noyi ta pochatkovoyi osvity v systemi neperervnoyi osvity.[Preparation of students for the implementation of continuity of preschool and primary education in the system of continuing education]. Nauka ta osvita. № 4. s. 61-63[in Ukrainian].

4. Hram H. P.(2016) Sensorno -piznaval'nyy rozvytok ditey druhoho roku zhyttya v nayblyzhchomu predmetnomu seredovyshchi. [Sensory -cognitive development of children in the second year of life in the immediate subject environment]. Zbirnyk naukovykh dopovidey. P International. Naukovo -praktychna konferentsiya. "Aktual'ni problemy suchasnoyi doshkil'noyi ta vyshchoyi osvity (30.052016 -31.05.2016) Varshava. Vydavets'. C. 78-82. [in Ukrainian].

5. Kalus'ka L. V.(2014) Kompleksna prohrama rozvytku, navchannya ta vykhovannya ditey doshkil'noho viku. [Comprehensive program of development, education and upbringing of preschool children].Ternopil': Mandrivets', 144 [in Ukrainian].

6. Koshel' V.M.(2019) Sensorna osvita malen'kykh ditey. [Sensory education of young children].Chernihiv: FOP Balikina O. V.,160 [in Ukrainian].

7. Nepomnyashcha I. (2015) Rozvytok slovesnoyi tvorchosti u ditey molodshoho shkil'noho viku. [Development of verbal creativity in children of primary school age]. PNPU im. K.D. Ushyns'kyy, Pedahohichnyy al'manakh: Zb.stud.nauk. statti Odesy. S. 240-244. [in Ukrainian] 